\title{
MAVS expression in alveolar macrophages is essential for host resistance against Aspergillus fumigatus
}

Xi Wang ${ }^{1}$, Cristina Cunha ${ }^{2,3}$, Madeleine S. Grau ${ }^{1}$, Shelly J. Robertson ${ }^{4}$, João F. Lacerda ${ }^{5,6}$, António Campos $\mathrm{Jr}^{7}$, Katrien Lagrou ${ }^{8,9}$, Johan Maertens ${ }^{8,10}$, Sonja M. Best ${ }^{4}$, Agostinho Carvalho ${ }^{2,3}$, Joshua J. Obar ${ }^{1, \#}$

${ }^{1}$ Geisel School of Medicine at Dartmouth, Department of Microbiology \& Immunology, Lebanon, $\mathrm{NH}$, USA

${ }^{2}$ Life and Health Sciences Research Institute (ICVS), School of Medicine, University of Minho, Braga, Portugal

${ }^{3}$ ICVS/3B's - PT Government Associate Laboratory, Braga/Guimarães, Portugal

${ }^{4}$ Laboratory of Virology, Rocky Mountain Laboratories, National Institute of Allergy and Infectious Diseases, NIH, Hamilton MT, USA.

${ }^{5}$ Instituto de Medicina Molecular, Faculdade de Medicina de Lisboa, Universidade de Lisboa, Lisboa, Portugal.

${ }^{6}$ Serviço de Hematologia e Transplantação de Medula, Hospital de Santa Maria, Lisboa, Portugal

${ }^{7}$ Serviço de Transplantação de Medula Óssea (STMO), Instituto Português de Oncologia do Porto, Porto, Portugal

${ }^{8}$ Department of Microbiology, Immunology and Transplantation, KU Leuven, Leuven, Belgium

${ }^{9}$ Clinical Department of Laboratory Medicine and National Reference Center for Medical Mycology, University Hospitals Leuven, Leuven, Belgium

${ }^{10}$ Department of Hematology, University Hospitals Leuven, Leuven, Belgium

Conflict of Interests: The authors have declared that no conflict of interest exists.

${ }^{\#}$ Corresponding author:

Joshua J. Obar

Geisel School of Medicine at Dartmouth

Department of Microbiology \& Immunology

1 Medical Center Drive

Lebanon, NH 03756

Telephone: +1 (603) 646-5384

Email: joshua.j.obar@dartmouth.edu 
medRxiv preprint doi: https://doi.org/10.1101/2021.08.07.21261611; this version posted August 8, 2021. The copyright holder for this preprint (which was not certified by peer review) is the author/funder, who has granted medRxiv a license to display the preprint in perpetuity.

It is made available under a CC-BY-NC-ND 4.0 International license .

\section{ABSTRACT}

40 Our recent data demonstrates a critical role of the RIG-I-like receptor (RLR) family in regulating

41 antifungal immunity against Aspergillus fumigatus in a murine model. However, the importance

42 of this pathway in humans and the cell type(s) which utilize this innate immune receptor to detect

43 A. fumigatus remains unresolved. Here we demonstrate that a polymorphism in human MAVS

44 present in the donor genome was associated with the incidence of invasive pulmonary aspergillosis

45 (IPA) in recipients of hematopoietic stem cell transplantation (HSCT). Moreover, in a separate

46 cohort of confirmed IPA patients, polymorphisms in the IFIHI gene alter the inflammatory

47 response, including interferon-responsive chemokines. Returning to our murine model, we now

48 demonstrate that $\mathrm{CD}_{11 \mathrm{c}^{+}}$alveolar macrophages require Mavs expression to maintain host

49 resistance against $A$. fumigatus. Our data support the role of MAVS signaling in mediating

50 antifungal immunity in both mice and human at least in part through the role of MAVS-dependent

51 signaling in alveolar macrophages.

52 
medRxiv preprint doi: https://doi.org/10.1101/2021.08.07.21261611; this version posted August 8, 2021. The copyright holder for this preprint (which was not certified by peer review) is the author/funder, who has granted medRxiv a license to display the preprint in perpetuity.

It is made available under a CC-BY-NC-ND 4.0 International license .

\section{INTRODUCTION}

Aspergillus fumigatus is a ubiquitous environmental mold that humans inhale on a daily basis. Individuals with normal immune systems readily clear A. fumigatus conidia from their airways without complications. In contrast, immunocompromised individuals are at significantly greater risk of developing invasive pulmonary aspergillosis (IPA), including those receiving chemotherapy treatments for cancer and patients receiving immunosuppressive regimens to prevent GVHD following hematopoietic stem cell or solid organ transplantation [1-5]. However, only a small proportion of immunosuppressed patients develop invasive fungal infections indicating that additional risk factors must exist. Numerous human studies have identified genetic polymorphisms in key antifungal pattern recognition receptors and inflammatory cytokines associated with fungal infections (reviewed in [6-8]). Thus, it is important to understand how these responses are coordinated in response to fungal infection of the lungs.

Recently, both type I and type III interferons have been shown to be essential for host resistance against pulmonary A. fumigatus challenge [9]. Both Dectin $1(\mathrm{Clec} 7 a)$ and MDA5 (Ifihl) are necessary to induce of the type I and type III interferon response following A. fumigatus challenge in the mouse model $[10,11]$. Engagement of Dectin 1 leads to Syk activation which drive IRF5 activation for the production of IFN $\beta$ following Candida albicans challenge [12]. MDA5 engagement by dsRNA leads to its interaction with MAVS resulting in the recruitment of IKK $\varepsilon$ and TBK1 that activate NFאB and IRF3 and IRF7, respectively, for the production of early cytokines and type I interferons [13]. Genetic polymorphisms within CLEC7A have been associated with increased risk of developing IPA [14-16], while the role for genetic polymorphisms within IFIH1 or MAVS regarding susceptibility to IPA has not been explored to date. 
medRxiv preprint doi: https://doi.org/10.1101/2021.08.07.21261611; this version posted August 8, 2021. The copyright holder for this preprint (which was not certified by peer review) is the author/funder, who has granted medRxiv a license to display the preprint in perpetuity. It is made available under a CC-BY-NC-ND 4.0 International license.

77 the production of interferon-dependent chemokines and risk for HSCT patients in developing IPA,

78 respectively. Interestingly, increased risk for developing IPA was associated with genetic variation

79 within MAVS only in the donor/hematopoietic compartment. Using our murine model, we identify

80 alveolar macrophages as a key hematopoietic cell in the induction of the MAVS-dependent

81 interferon response which is necessary for host resistance against A. fumigatus. Overall, our study

82 reveals a critical role for MDA5/MAVS in host anti-fungal immunity in both mice and humans. 
medRxiv preprint doi: https://doi.org/10.1101/2021.08.07.21261611; this version posted August 8, 2021. The copyright holder for this preprint (which was not certified by peer review) is the author/funder, who has granted medRxiv a license to display the preprint in perpetuity.

It is made available under a CC-BY-NC-ND 4.0 International license .

RESULTS

85

Single Nucleotide Polymorphisms (SNPs) in IFIH1 and MAVS influence the risk for developing invasive pulmonary aspergillosis.

Our recent mouse data suggests that MDA5/MAVS signaling is critical in maintaining host

resistance against pulmonary challenge with A. fumigatus [11]. Therefore, we wanted to explore the role of these molecules in a human cohort comprised of 460 HSCT patients (Supplemental Table 1). Missense SNPs within the coding region of IFIH1 (rs1990760 and rs3747517) are associated with autoimmune conditions, particularly interferonopathies [17]. Moreover, a missense SNP in MAVS (rs17857295) is associated with altered type I interferon regulation [18]. While an individual genotype for each SNP was not associated with risk of developing IPA the autoimmune risk allele in IFIH1 rs1990760 has been shown to work in a dominant fashion [17]. Notably, we found a significant association between the CC genotype at rs1990760 in IFIHI and the risk of developing IPA in HSCT recipients (Figure 1A). This increased risk occurred when the variant was carried by the recipient in a recessive genetic model, but not when it was carried by the donor. In contrast, no association between the IFIH1 rs3747517 SNP and the risk of developing IPA was found (Figure 1B). Additionally, we also found a significant association between the MAVS rs17857295 SNP and the risk of developing IPA in HSCT recipients (Figure 1C). This increased risk occurred when the variant was carried by the donor in a recessive genetic 
medRxiv preprint doi: https://doi.org/10.1101/2021.08.07.21261611; this version posted August 8, 2021. The copyright holder for this preprint (which was not certified by peer review) is the author/funder, who has granted medRxiv a license to display the preprint in perpetuity.

It is made available under a CC-BY-NC-ND 4.0 International license .

To demonstrate a functional effect of the rs1990760 SNP in IFIHI and the associated

108

109

110

111

112

113

114

115

116

117

118

119

120

121

122

123

124

125

126

127

128

129

amino acid substitution on the function of MDA5, we analyzed the inflammatory response in the bronchoalveolar lavage fluid (BALF) of 23 patients with IPA after stratification by genotypes at rs 1990760 in IFIH1. We found that individuals with the CC genotype, which is associated with increased risk of developing IPA (Figure 1A), had a significant reduction in IP-10 (CXCL10), RANTES (CCL5), and MIP-1 $\alpha$ (CCL3), but not IL-8 and GRO $\alpha$ (CXCL1) (Figure 1D). IP-10 (CXCL10), RANTES (CCL5), and MIP-1 $\alpha$ (CCL3) are known to be interferon-responsive genes, while IL-8 and GRO $\alpha$ (CXCL1) are not [19]. In the BALF samples from this patient cohort, the levels of IFN- $\alpha$ were below the detection limit (data not shown). Given the relatively rare frequency of the rs17857295 genotype in $M A V S$, it was not possible to analyze cytokine production according to MAVS genotype in the BAL samples (data not shown). Overall, these data support an important role for MDA5/MAVS signaling in regulating the inflammatory response and host resistance against Aspergillus spp. in humans.

\section{Deletion of Mavs in CD11c ${ }^{+}$cells result in increased susceptibility to Aspergillus fumigatus in} mice.

Given the observation that patients in the HSCT cohort with the MAVS rs 17857295 polymorphism within the donor population had altered risk for developing IPA, we next wanted to assess which hematopoietic cell population(s) in our invasive aspergillosis murine model relies on Mavs to maintain host resistance against A. fumigatus. To directly address which cells must express Mavs we utilized the recently developed Mavs $^{(f l f l)} \times$ Itgax-Cre conditional knock-out model, hereafter referred to as $\mathrm{Mavs}^{(\mathrm{Cd11} / \mathrm{Cd11c})}$, that will delete Mavs in all CD11c-expressing cells [20], including both dendritic cells and alveolar macrophages. To test of role of Mavs expression 
medRxiv preprint doi: https://doi.org/10.1101/2021.08.07.21261611; this version posted August 8, 2021. The copyright holder for this preprint (which was not certified by peer review) is the author/funder, who has granted medRxiv a license to display the preprint in perpetuity.

It is made available under a CC-BY-NC-ND 4.0 International license .

in CD11c-expressing cells for the maintenance of host resistance against A. fumigatus, we

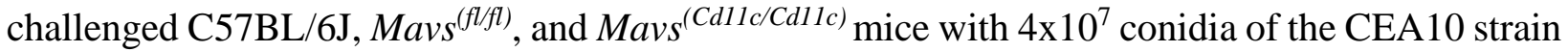

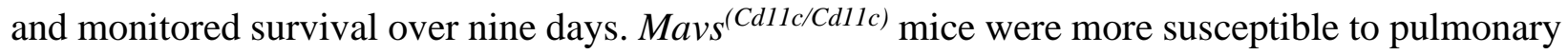
challenge with A. fumigatus than either C57BL/6J or Mavs ${ }^{(f l f l)}$ mice (Figure 2A; Mantel-Cox log rank test, $\mathrm{p}<0.0001)$. Mice completely lacking either Ifihl or Mavs have decreased neutrophil recruitment, which was associated with increased fungal germination after pulmonary challenge with A. fumigatus [11]. Thus, we assessed fungal germination in the lung by histological analysis at $48 \mathrm{~h}$ after conidial instillation. Strikingly, GMS staining of lung tissue from $\operatorname{Mavs}^{(\mathrm{Cd} 11 \mathrm{c} / \mathrm{Cd} 11 \mathrm{c})}$ mice revealed high levels of A. fumigatus germination at this time compared with control Mavs ${ }^{(f l f l)}$ mice (Figure 2B). When the percentage of germinated A. fumigatus was quantified, Mavs ${ }^{(f l f l)}$ mice displayed low levels of fungal germination $(23.5 \% \pm 9.1)$ compared with $\mathrm{Mavs}^{(\mathrm{Cd11} / \mathrm{Cd11c})}$ mice $(60.1 \% \pm 8.2)$. Finally, we assessed inflammatory cell accumulation in the airways. The increased

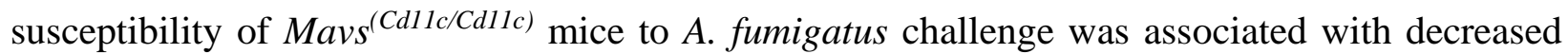
accumulation of neutrophils in the airways compared with $M a v s^{(f l / f l)}$ mice (Figure 2C). These data match our prior observations with mice completely lacking either Ifihl or Mavs having increased IPA susceptibility [11], suggesting that Mavs expression within CD11c-expressing cells is critical for host resistance against $A$. fumigatus challenge.

\section{Alveolar macrophage transfer to $\operatorname{Mavs}^{(C d 11 c / C d 11 c)}$ conditional knock-out mice reduces their} susceptibility to Aspergillus fumigatus in mice.

Multiple cells in the lungs can express Igtax (CD11c) including alveolar macrophages, $\mathrm{CD} 103^{+}$dendritic cells, CD11b ${ }^{+}$dendritic cells, monocyte-derived dendritic cells, and plasmacytoid dendritic cells, all of which have be implicated in the antifungal immune response 
medRxiv preprint doi: https://doi.org/10.1101/2021.08.07.21261611; this version posted August 8, 2021. The copyright holder for this preprint (which was not certified by peer review) is the author/funder, who has granted medRxiv a license to display the preprint in perpetuity.

It is made available under a CC-BY-NC-ND 4.0 International license.

against A. fumigatus [21-27]. Utilizing the publicly available data assembled by the ImmGen Consortium [28], in the lungs we see that Mavs is highly expressed in Siglec $\mathrm{F}^{+}$alveolar macrophages, but also moderately expressed in both monocytes and dendritic cells (data not shown). Interestingly, following RSV infection alveolar macrophages have been shown to be the key cell type for initiating the type I interferon through a MAVS-dependent mechanism [29, 30]. While alveolar macrophages largely populate the lungs during embryogenesis and are maintained by local proliferation during homeostasis [31, 32] following conditioning for HSC transplantation alveolar macrophage can be repopulated from the donor HSC compartment [33-36]. Therefore, to specifically address the role of Mavs in alveolar macrophages, we purified Siglec $\mathrm{F}^{+}$cells from the lungs of naïve $\operatorname{Mavs}^{(f l f l)}$ or $\operatorname{Mavs}^{(C d 11 c / C d 11 c)}$ mice and transferred $5 \times 10^{5}$ Siglec $\mathrm{F}^{+}$cells

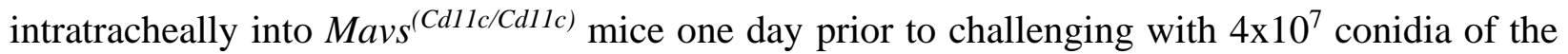
CEA10 strain (Figure 3A). Forty-eight hours after challenge, we examined the lungs by GMS staining of lung tissue from $\operatorname{Mavs}^{(C d 11 c / C d 11 c)}$ mice receiving the $\operatorname{Mavs}^{(C d 11 c / C d 11 c)}$ Siglec $\mathrm{F}^{+}$cells and revealed the presence of high levels of germinated A. fumigatus $(68.1 \% \pm 12.6)$, while that was not observed to the same extent in $\operatorname{Mavs}^{(\mathrm{Cd11} / \mathrm{Cd11c)}}$ mice receiving the $\mathrm{Mavs}^{(f l f l)}$ Siglec $\mathrm{F}^{+}$cells $(31.4 \% \pm 6.7)$ (Figure 3B). This is in line with control $\operatorname{Mavs}^{(C d 11 c / C d 11 c)}$ mice or Mavs ${ }^{(f l f l)}$ mice receiving DMEM (vehicle) administered intratracheally. When we examined the accumulation of leukocytes in the airways by differential cytospin analysis we found that $\mathrm{Mavs}^{(\mathrm{Cd11c/Cd11c)}}$ mice

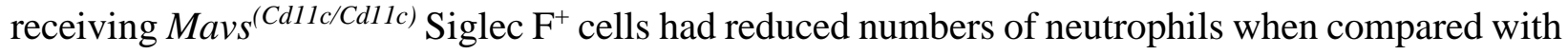
$\operatorname{Mavs}^{(C d 11 c / C d 11 c)}$ mice receiving $\operatorname{Mavs}^{(f l f l)}$ Siglec $\mathrm{F}^{+}$cells (Figure 3C). Strikingly, when we

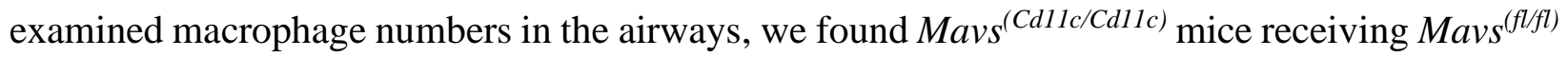
Siglec $\mathrm{F}^{+}$cells had many macrophages present, but $M a v s^{(C d 11 c / C d 11 c)}$ mice receiving $M a v s^{(C d 11 c / C d 11 c)}$ Siglec $\mathrm{F}^{+}$cells had few macrophages in their airways at 48 hours post-inoculation with $A$. 
medRxiv preprint doi: https://doi.org/10.1101/2021.08.07.21261611; this version posted August 8, 2021. The copyright holder for this preprint (which was not certified by peer review) is the author/funder, who has granted medRxiv a license to display the preprint in perpetuity. It is made available under a CC-BY-NC-ND 4.0 International license.

176 fumigatus (Figure 3D). Importantly, the decrease in macrophages in the airways is not observed in

177 naïve $\operatorname{Mavs}^{(C d 11 / / C d 11 c)}$ mice (Supplemental Figure 2A). Additionally, Mavs ${ }^{(C d 11 / / C d 11 c)}$ mice

178 receiving an i.t. transfer of Mavs ${ }^{(\text {CdIlc/Cdllc) }}$ Siglec $\mathrm{F}^{+}$cells $24 \mathrm{~h}$ prior only had a moderate decrease

179 in alveolar macrophage numbers (Supplemental Figure 2B). These data demonstrate that Mavs

180 expression within Siglec $\mathrm{F}^{+}$alveolar macrophages is critical for host resistance against $A$.

181 fumigatus.

182 
medRxiv preprint doi: https://doi.org/10.1101/2021.08.07.21261611; this version posted August 8, 2021. The copyright holder for this preprint (which was not certified by peer review) is the author/funder, who has granted medRxiv a license to display the preprint in perpetuity.

It is made available under a CC-BY-NC-ND 4.0 International license .

\section{DISCUSSION}

Humans inhale Aspergillus fumigatus spores on a daily basis, but individuals with healthy immune systems readily clear A. fumigatus conidia from their airways without problems. One lung sentinel cell that can be critical in the clearance of $A$. fumigatus is the alveolar macrophage. Alveolar macrophages are known to phagocytose and destroy A. fumigatus [25], but their role in host resistance has remained controversial [27, 37]. Patients undergoing HSCT are at increased risk of developing IPA [1-5]. In patients undergoing HSCT, alveolar macrophages are dysfunctional [35] and found at decreased in numbers [34-36] for at least 50 days posttransplantation. Thus, it is important to understand the role of alveolar macrophages in the initial inflammatory response induced by A. fumigatus. These lung sentinel alveolar macrophages are also known to participate in the inflammatory response induced by A. fumigatus [38], but their role in driving the interferon response following A. fumigatus challenge was not addressed. During respiratory syncytial virus infection alveolar macrophages have been demonstrated to be key drivers of the type I interferon response through a MAVS-dependent mechanism [29, 30]. We recently describe a critical role for MDA5/MAVS-dependent induction of interferons following $A$. fumigatus challenge [11], but the cellular localization of MAVS-dependent signaling was not elucidated. Here we demonstrated that Mavs expression in alveolar macrophages was at least partially necessary for host resistance against A. fumigatus, through the regulation of neutrophil accumulation in the lung for the prevention of fungal growth. While alveolar macrophage transfer

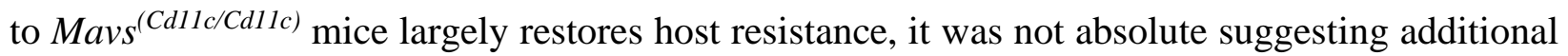
$\mathrm{CD}_{11 \mathrm{c}^{+}}$cells might require Mavs expression for resistance. One potential candidate would be plasmacytoid dendritic cells that are known to produce type I interferons after fungal challenge [21] and are essential for host resistance A. fumigatus [39], but the importance of MAVS signaling 
medRxiv preprint doi: https://doi.org/10.1101/2021.08.07.21261611; this version posted August 8, 2021. The copyright holder for this preprint (which was not certified by peer review) is the author/funder, who has granted medRxiv a license to display the preprint in perpetuity.

It is made available under a CC-BY-NC-ND 4.0 International license.

in plasmacytoid dendritic cells in driving the interferon response remains controversial. The role of MAVS signaling in other CD11 $\mathrm{c}^{+}$cell populations will be explored in future studies. Alveolar macrophages also participate in the inflammatory response to other fungal pathogens including Cryptococcus neoformans [40], Pneumocystis spp. [41], and Rhizopus spp. [42]. Interestingly, heterogeneity within the alveolar macrophage population has been demonstrated particularly in regard to CXCL2 expression [40], which could be important in our findings showing that the mice lacking Ifihl or Mavs have decreased neutrophil accumulation following A. fumigatus challenge [11].

While our previous studies have shown the importance of MDA5/MAVS signaling [11] and type I/III interferons [9] in host resistance against A. fumigatus in the murine model, the importance of these pathways in humans has not been described. Herein, we have found that antifungal role of MDA5/MAVS signaling is also critical in humans. Our data from a cohort of HSCT patients demonstrate that SNPs in IFIH (rs1990760) and MAVS (rs 17857295) are associated with an altered risk of developing IPA. Interestingly, SNPs within IFIHI have been associated with numerous autoimmune diseases, particularly those that are highly dependent on type I interferons for their progression [17, 43]. Recent evidence suggests that the autoimmune risk genotype of the rs1990760 SNP in IFIH1 (TT) has functional consequences in human PBMCs, specifically it is associated with elevated basal levels of IFNBI [17]. Knock-in of the IFIHI rs 1990760 autoimmune risk genotype (TT) into mice not only recapitulates the susceptibility to autoimmune diseases, but also results in increased host resistance against encephalomyocarditis virus (ECMV), a picornavirus specifically recognized by MDA5 [44], and elevated Ifnb1 expression [17]. Moreover, in human pancreatic islets it has been shown that the IFIHI rs 1990760 TC genotype also drove enhanced interferon signaling after Coxsackievirus infection [45]. This 
medRxiv preprint doi: https://doi.org/10.1101/2021.08.07.21261611; this version posted August 8, 2021. The copyright holder for this preprint (which was not certified by peer review) is the author/funder, who has granted medRxiv a license to display the preprint in perpetuity.

It is made available under a CC-BY-NC-ND 4.0 International license.

enhanced interferon response during Coxsackievirus infection was associated with greater signaling from the peroxisomes by the IFIH1 rs1990760 TC genotype [45], which has previously been shown to preferentially induce a type III interferon response [46, 47]. Interestingly, our SNP analysis of a human HSCT cohort found that the T allele of IFIH1 rs1990760, which as just mentioned is associated with an increased interferon response [17, 45], was associated with a reduced risk for the development of IPA. In addition to the IFIHI rs1990760 SNP, we also found a clinical association with the rs17857295 SNP in MAVS with the risk of developing IPA after HSCT. Much less is known about the functional outcome of the rs17857295 SNP in MAVS, but one report suggests overexpression of the GG genotype in 293T cells stably knocked-down for the endogenous MAVS allele resulted in an inability to induce Ifnbl expression following PolyI:C stimulation [18]. Overall, our analysis suggests that HSCT patients harboring these SNPs display a reduced ability to trigger an interferon response and are at greater risk of developing IPA.

In contrast to our clinical data from HSCT patients who develop IPA, the T allele at rs1990760 in IFIH1 is associated with an increased risk for the development of chronic mucocutaneous candidiasis [48]. Again, the T allele at rs1990760 is associated with an increased interferon response $[17,45]$, but the lack of IFNAR-dependent signaling leads to increased susceptibility to invasive candidiasis in mice [12]. In their study Netea and colleagues did not observe altered Ifnb expression in the absence of MDA5 after stimulation with Candida albicans hyphae [48], but a role for MDA5 in regulating other interferons was not explored. Our data with A. fumigatus suggests that MDA5/MAVS-signaling are more important in the regulation of type III interferons (IFN $\lambda /$ IL-28), rather than type I interferons (IFN $\alpha / \beta)$. Excessive inflammation and tissue pathology can be critical in mediating disease during invasive candidiasis [49]. Rivera and colleagues demonstrated that type III interferon (IFN $\lambda /$ IL-28) signaling enhances the production 
medRxiv preprint doi: https://doi.org/10.1101/2021.08.07.21261611; this version posted August 8, 2021. The copyright holder for this preprint (which was not certified by peer review) is the author/funder, who has granted medRxiv a license to display the preprint in perpetuity. It is made available under a CC-BY-NC-ND 4.0 International license .

252 of reactive oxygen species by neutrophils following A. fumigatus [9], which could enhance disease

253 during invasive candidiasis. Thus, there appears to be an interesting dichotomy in MDA5 signaling

254 that is crucial for tuning host resistance against different fungal pathogens and warrants further

255 research. 
medRxiv preprint doi: https://doi.org/10.1101/2021.08.07.21261611; this version posted August 8, 2021. The copyright holder for this preprint (which was not certified by peer review) is the author/funder, who has granted medRxiv a license to display the preprint in perpetuity.

It is made available under a CC-BY-NC-ND 4.0 International license .

METHODS

257 Mice and Aspergillus fumigatus challenge model. Mavs ${ }^{(f l f l)}$ and Mavs ${ }^{(f l f l)} x$ Itgax-Cre mice [20]

258 were bred in-house at Geisel School of Medicine at Dartmouth. C57BL/6J mice were purchased

259 from Jackson Laboratory. All mice were 8-16 weeks of age at the time of challenge.

260

261

Preparation of Aspergillus fumigatus conidia and murine challenge model. A. fumigatus CEA10

262

strains were used for this study. A. fumigatus was grown on glucose minimal media (GMM) agar

263

plates for 3 days at $37^{\circ} \mathrm{C}$. Conidia were harvested by adding $0.01 \%$ Tween 80 to plates and gently

264

scraping conidia from the plates using a cell scraper. Conidia were then filtered through sterile

Miracloth, were washed, and resuspended in phosphate buffered saline (PBS), and counted on a hemocytometer.

Mice were challenged with A. fumigatus conidia by the intratracheal (i.t.) route. Mice were anesthetized by inhalation of isoflurane; subsequently, mice were challenged i.t. with $\sim 4 \times 10^{7} \mathrm{~A}$. fumigatus conidia in a volume of $100 \mu \mathrm{l}$ PBS. At the indicated time after A. fumigatus challenge, mice were euthanized using carbon dioxide. Bronchoalveolar lavage fluid (BALF) was collected

271 by washing the lungs with $2 \mathrm{ml}$ of PBS containing $0.05 M$ EDTA. BALF was clarified by 272 centrifugation and stored at $-20^{\circ} \mathrm{C}$ until analysis. After centrifugation, the cellular component of 273 the BALF was resuspended in $200 \mu \mathrm{l}$ of PBS and total BAL cells were determined by 274 hemocytometer count. BALF cells were subsequently spun onto glass slides using a Cytospin4 275 cytocentrifuge (Thermo Scientific) and stained with the Hema $3^{\text {TM }}$ Stat Pack (Fisher Scientific) 276 stain set for differential counting. For histological analysis lungs were filled with and stored in

$27710 \%$ buffered formalin phosphate for at least 24 hours. Lungs were then embedded in paraffin and sectioned into 5-micron sections. Sections were stained with Grocott-Gomori methenamine silver 
medRxiv preprint doi: https://doi.org/10.1101/2021.08.07.21261611; this version posted August 8, 2021. The copyright holder for this preprint (which was not certified by peer review) is the author/funder, who has granted medRxiv a license to display the preprint in perpetuity.

It is made available under a CC-BY-NC-ND 4.0 International license .

279 (GMS) using standard histological techniques to assess lung inflammatory infiltrates and fungal germination, respectively. Representative pictures of lung sections were taken using an Olympus

281 BX50WI microscope with a QImaging Retiga 2000R camera.

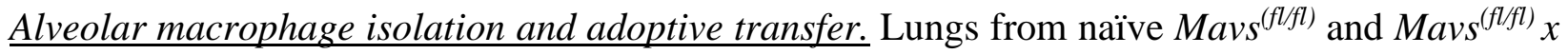
Itgax-Cre were perfused with 20-30 ml of PBS. Lungs were then removed, injected with $700 \mu 1$ of collagenase buffer [10ml RPMI, 1ml FBS, $25 \mu \mathrm{l} 0.5 M \mathrm{CaCl}_{2}, 25 \mu \mathrm{l} 0.5 M \mathrm{MgCl}_{2}, 50 \mu \mathrm{HEPES}$, $100 \mu \mathrm{l}$ L-glutamine, $100 \mu$ l Penn-Strep, $2 \mu$ gentamycin, $25 \mu$ l DNase (VWR, Catalog \# 77001 900), and $2 \mathrm{ml}$ Liberase (Sigma-Aldrich)], and finally placed in $15 \mathrm{ml}$ conical tube containing 2 $\mathrm{ml}$ of collagenase buffer. Lungs were digested or $30 \mathrm{~min}$ at $37^{\circ} \mathrm{C}$ while shaking at $160-180 \mathrm{rpm}$. added to each tube. Lungs were pushed through a $70 \mu \mathrm{m}$ filter to generate a single cell suspension. Single cell lung suspensions were labeled with anti-Siglec-F MicroBeads (Miltenyi Biotec, Cat. No. 130-118-513) and selected for using LS Columns (Miltenyi Biotec, Cat. No. 130-042-401).

Siglec $\mathrm{F}^{+}$were eluted from the column, spun down, and resuspended in DMEM at $5 \times 10^{6}$ cells per

Human HSCT cohort for SNP analysis. A total of 460 hematologic patients undergoing allogeneic 
medRxiv preprint doi: https://doi.org/10.1101/2021.08.07.21261611; this version posted August 8, 2021. The copyright holder for this preprint (which was not certified by peer review) is the author/funder, who has granted medRxiv a license to display the preprint in perpetuity.

It is made available under a CC-BY-NC-ND 4.0 International license .

301 from the European Organization for Research and Treatment of Cancer/Mycology Study Group

302 (EORTC/MSG) [50]. Exclusion criteria included diagnosis of 'possible' IPA, infection with

303 invasive molds other than Aspergillus spp. or history of pre-transplant mold infection. Study

304 approval was obtained from the institutional review boards (SECVS-125/2014, HSM-632/14 and

305 CES.26/015) and from the National Data Protection Commission (CNPD, 1950/2015) and was in

306 compliance with all local relevant ethical regulations.

Genomic DNA was isolated from whole blood of patients using the QIAcube automated

308

309

310

311

312

Cytokine analysis of BALF from human IPA patients. BALF and blood samples were collected from hospitalized adult patients ( $\geq 18$ years of age) at the Leuven University Hospitals, Leuven, Belgium, as previously described [51]. This study was approved and carried out in accordance with recommendations of the Ethics Subcommittee for Life and Health Sciences of the University of Minho, Portugal (SECVS-125/2014), and the Ethics Committee of the University Hospitals of Leuven, Belgium. Written informed consent was obtained from all subjects in accordance with the Declaration of Helsinki.

For this cytokine analysis, twenty-three cases of "probable" or "proven" IPA were identified according to the standard criteria from the European Organization for Research and Treatment of Cancer/Mycology Study Group (EORTC/MSG) [50] and included for cytokine 
medRxiv preprint doi: https://doi.org/10.1101/2021.08.07.21261611; this version posted August 8, 2021. The copyright holder for this preprint (which was not certified by peer review) is the author/funder, who has granted medRxiv a license to display the preprint in perpetuity.

It is made available under a CC-BY-NC-ND 4.0 International license .

323

324

325

326

327

328

329

330

331

332

333

334

335

336

337

338 compliance with all local relevant ethical regulations.

analysis. Genomic DNA was isolated from EDTA venous blood and genotyped for the IFIH1 rs 1990760 polymorphism. Cytokine levels were determined using the Cytokine \& Chemokine 34Plex Human ProcartaPlex and stratified based on their IFIH1 rs1990760 genotype.

Statistical analysis. Statistical significance for in vitro and ex vivo data was determined by a MannWhitney U test, one-way ANOVA using a Bonferroni post-test, or Kruskal-Wallis one-way ANOVA with Dunn's post-test through the GraphPad Prism 7 software as outlined in the figure legends. Mouse survival data were analyzed with the Mantel-Cox log rank test using GraphPad Prism. For the human HSCT cohort, the probability of IPA resulting from IFIH1 and MAVS SNPs was analyzed using the cumulative incidence method and compared using Gray's test [52]. Cumulative incidences were computed with the cmprsk package for R version 2.10.1 [53], with censoring of data at the date of last follow-up visit and defining relapse and death as competing events. A period of 24 months after transplant was chosen to include all cases of IPA.

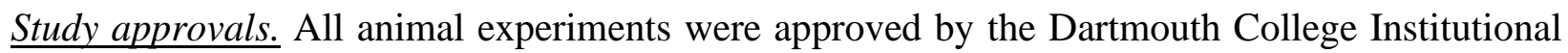
Animal Care and Use Committee under protocol number 00002168. For our human studies approval was obtained from the institutional review boards (SECVS-125/2014, HSM-632/14 and CES.26/015) and from the National Data Protection Commission (CNPD, 1950/2015) and was in 
medRxiv preprint doi: https://doi.org/10.1101/2021.08.07.21261611; this version posted August 8, 2021. The copyright holder for this preprint (which was not certified by peer review) is the author/funder, who has granted medRxiv a license to display the preprint in perpetuity.

It is made available under a CC-BY-NC-ND 4.0 International license .

\section{AUTHOR CONTRIBUTIONS}

344 Conceived and designed the experiments: XW, AC, JJO. Performed the experiments: XW, CC,

345 MG. Analyzed the data: XW, CC, MG, AC, JJO. Provided clinical samples: JFL, AC Jr, KL, JM.

346 Wrote the paper: XW, JJO.

347

\section{ACKNOWLEDGEMENTS}

349 Thank you to Drs. Robert Cramer, Claudia Jakubzick, and David Leib (Geisel School of Medicine

350 at Dartmouth) for helpful discussion on this project. Research in this study was supported in part

351 by institutional startup funds to JJO in part through the Dartmouth Lung Biology Center for

352 Molecular, Cellular, and Translational Research grant P30 GM106394 (PI: Bruce A. Stanton) and

353 Center for Molecular, Cellular and Translational Immunological Research grant P30 GM103415

354 (PI: William R. Green). JJO was partially supported by a Munck-Pfefferkorn Award from

355 Dartmouth College and NIH R01 AI139133 grant. SMB is supported by the Division of Intramural

356 Research, National Institutes of Health, National Institute of Allergy and Infectious Diseases. AC

357 and CC were supported by the Fundação para a Ciência e Tecnologia (FCT) (PTDC/SAU-

358 SER/29635/2017, PTDC/MED-GEN/28778/2017, UIDB/50026/2020, UIDP/50026/2020, and

359 CEECIND/04058/2018), the Northern Portugal Regional Operational Programme (NORTE 2020),

360 under the Portugal 2020 Partnership Agreement, through the European Regional Development

361 Fund (ERDF) (NORTE-01-0145-FEDER-000039), the European Union's Horizon 2020 research

362 and innovation programme under grant agreement no. 847507, and the "la Caixa" Foundation (ID

363 100010434) and FCT under the agreement LCF/PR/HR17/52190003. The funders had no role in

364 the preparation or publication of the manuscript. 
medRxiv preprint doi: https://doi.org/10.1101/2021.08.07.21261611; this version posted August 8, 2021. The copyright holder for this preprint (which was not certified by peer review) is the author/funder, who has granted medRxiv a license to display the preprint in perpetuity. It is made available under a CC-BY-NC-ND 4.0 International license .

\section{REFERENCES}

1. Baddley, J.W., et al., Factors associated with mortality in transplant patients with invasive aspergillosis. Clin Infect Dis, 2010. 50(12): p. 1559-67.

2. Steinbach, W.J., et al., Clinical epidemiology of 960 patients with invasive aspergillosis from the PATH Alliance registry. J Infect, 2012. 65(5): p. 453-64.

3. Garcia-Vidal, C., et al., Epidemiology of invasive mold infections in allogeneic stem cell transplant recipients: biological risk factors for infection according to time after transplantation. Clin Infect Dis, 2008. 47(8): p. 1041-50.

4. Upton, A., et al., Invasive aspergillosis following hematopoietic cell transplantation: outcomes and prognostic factors associated with mortality. Clin Infect Dis, 2007. 44(4): p. 531-40.

5. Thompson, G.R., 3rd and T.F. Patterson, Pulmonary aspergillosis. Semin Respir Crit Care Med, 2008. 29(2): p. 103-10.

6. Romani, L., Immunity to fungal infections. Nat Rev Immunol, 2011. 11(4): p. 275-88.

7. Cunha, C., et al., Human genetic susceptibility to invasive aspergillosis. PLoS Pathog, 2013. 9(8): p. e1003434.

8. Campos, C.F., et al., Host Genetic Signatures of Susceptibility to Fungal Disease. Curr Top Microbiol Immunol, 2019. 422: p. 237-263.

9. $\quad$ Espinosa, V., et al., Type III interferon is a critical regulator of innate antifungal immunity Science Immunology, 2017. 2(16): p. eaan5357.

10. Dutta, O., et al., Dectin-1 Promotes Type I and III Interferon Expression to Support Optimal Antifungal Immunity in the Lung. Front Cell Infect Microbiol, 2020. 10: p. 321.

11. Wang, X., et al., MDA5 Is an Essential Sensor of a Pathogen-Associated Molecular Pattern Associated with Vitality That Is Necessary for Host Resistance against Aspergillus fumigatus. J Immunol, 2020. 205(11): p. 3058-3070.

12. del Fresno, C., et al., Interferon-beta production via Dectin-1-Syk-IRF5 signaling in dendritic cells is crucial for immunity to C. albicans. Immunity, 2013. 38(6): p. 1176-86.

13. Loo, Y.M. and M. Gale, Jr., Immune signaling by RIG-I-like receptors. Immunity, 2011. 34(5): p. 680-92.

14. Cunha, C., et al., Dectin-1 Y238X polymorphism associates with susceptibility to invasive aspergillosis in hematopoietic transplantation through impairment of both recipient-and donor-dependent mechanisms of antifungal immunity. Blood, 2010. 116(24): p. 5394-402. 
medRxiv preprint doi: https://doi.org/10.1101/2021.08.07.21261611; this version posted August 8, 2021. The copyright holder for this preprint (which was not certified by peer review) is the author/funder, who has granted medRxiv a license to display the preprint in perpetuity. It is made available under a CC-BY-NC-ND 4.0 International license .

15. Sainz, J., et al., Dectin-1 and DC-SIGN polymorphisms associated with invasive pulmonary Aspergillosis infection. PLoS One, 2012. 7(2): p. e32273.

16. Fisher, C.E., et al., Validation of single nucleotide polymorphisms in invasive aspergillosis following hematopoietic cell transplantation. Blood, 2017. 129(19): p. 2693-2701.

17. Gorman, J.A., et al., The A946T variant of the RNA sensor IFIH1 mediates an interferon program that limits viral infection but increases the risk for autoimmunity. Nat Immunol, 2017. 18(7): p. 744-752.

18. Xing, F., et al., Alteration of Antiviral Signalling by Single Nucleotide Polymorphisms (SNPs) of Mitochondrial Antiviral Signalling Protein (MAVS). PLoS One, 2016. 11(3): p. e0151173.

19. Bauer, J.W., et al., Elevated serum levels of interferon-regulated chemokines are biomarkers for active human systemic lupus erythematosus. PLoS Med, 2006. 3(12): p. e491.

20. Dutta, M., et al., A Systems Approach Reveals MAVS Signaling in Myeloid Cells as Critical for Resistance to Ebola Virus in Murine Models of Infection. Cell Rep, 2017. 18(3): p. 816829.

21. Ramirez-Ortiz, Z.G., et al., A nonredundant role for plasmacytoid dendritic cells in host defense against the human fungal pathogen Aspergillus fumigatus. Cell Host Microbe, 2011. 9(5): p. 415-24.

22. Espinosa, V., et al., Inflammatory monocytes orchestrate innate antifungal immunity in the lung. PLoS Pathog, 2014. 10(2): p. e1003940.

23. Hohl, T.M., et al., Inflammatory monocytes facilitate adaptive CD4 T cell responses during respiratory fungal infection. Cell Host Microbe, 2009. 6(5): p. 470-81.

24. Zelante, T., et al., CD103(+) Dendritic Cells Control Th17 Cell Function in the Lung. Cell Rep, 2015. 12(11): p. 1789-801.

25. Ibrahim-Granet, O., et al., Phagocytosis and intracellular fate of Aspergillus fumigatus conidia in alveolar macrophages. Infect Immun, 2003. 71(2): p. 891-903.

26. Grimm, M.J., et al., Monocyte- and macrophage-targeted NADPH oxidase mediates antifungal host defense and regulation of acute inflammation in mice. J Immunol, 2013. 190(8): p. 4175-84.

27. Bhatia, S., et al., Rapid host defense against Aspergillus fumigatus involves alveolar macrophages with a predominance of alternatively activated phenotype. PLoS One, 2011. 6(1): p. e15943. 
medRxiv preprint doi: https://doi.org/10.1101/2021.08.07.21261611; this version posted August 8, 2021. The copyright holder for this preprint (which was not certified by peer review) is the author/funder, who has granted medRxiv a license to display the preprint in perpetuity. It is made available under a CC-BY-NC-ND 4.0 International license .

28. Heng, T.S., M.W. Painter, and C. Immunological Genome Project, The Immunological Genome Project: networks of gene expression in immune cells. Nat Immunol, 2008. 9(10): p. 1091-4.

29. Goritzka, M., et al., Alveolar macrophage-derived type I interferons orchestrate innate immunity to RSV through recruitment of antiviral monocytes. J Exp Med, 2015. 212(5): p. 699-714.

30. Kirsebom, F.C.M., et al., Neutrophil recruitment and activation are differentially dependent on MyD88/TRIF and MAVS signaling during RSV infection. Mucosal Immunol, 2019. 12(5): p. 1244-1255.

31. Guilliams, M., et al., Alveolar macrophages develop from fetal monocytes that differentiate into long-lived cells in the first week of life via GM-CSF. J Exp Med, 2013. 210(10): p. 1977-92.

32. Svedberg, F.R., et al., The lung environment controls alveolar macrophage metabolism and responsiveness in type 2 inflammation. Nat Immunol, 2019. 20(5): p. 571-580.

33. Zinter, M.S. and J.R. Hume, Effects of Hematopoietic Cell Transplantation on the Pulmonary Immune Response to Infection. Front Pediatr, 2021. 9: p. 634566.

34. Thomas, E.D., et al., Direct evidence for a bone marrow origin of the alveolar macrophage in man. Science, 1976. 192(4243): p. 1016-8.

35. Winston, D.J., et al., Alveolar macrophage dysfunction in human bone marrow transplant recipients. Am J Med, 1982. 73(6): p. 859-66.

36. Nakata, K., et al., Augmented proliferation of human alveolar macrophages after allogeneic bone marrow transplantation. Blood, 1999. 93(2): p. 667-73.

37. Mircescu, M.M., et al., Essential role for neutrophils but not alveolar macrophages at early time points following Aspergillus fumigatus infection. J Infect Dis, 2009. 200(4): p. 64756.

38. Dubourdeau, M., et al., Interaction of Aspergillus fumigatus with the alveolar macrophage. Med Mycol, 2006. 44(Supplement_1): p. S213-S217.

39. Guo, Y., et al., During Aspergillus Infection, Monocyte-Derived DCs, Neutrophils, and Plasmacytoid DCs Enhance Innate Immune Defense through CXCR3-Dependent Crosstalk. Cell Host Microbe, 2020: p. doi: 10.1016/j.chom.2020.05.002.

40. Xu-Vanpala, S., et al., Functional heterogeneity of alveolar macrophage population based on expression of CXCL2. Sci Immunol, 2020. 5(50). 
medRxiv preprint doi: https://doi.org/10.1101/2021.08.07.21261611; this version posted August 8, 2021. The copyright holder for this preprint (which was not certified by peer review) is the author/funder, who has granted medRxiv a license to display the preprint in perpetuity. It is made available under a CC-BY-NC-ND 4.0 International license .

41. Bhagwat, S.P., et al., Intrinsic Programming of Alveolar Macrophages for Protective Antifungal Innate Immunity Against Pneumocystis Infection. Front Immunol, 2018. 9: p. 2131.

42. Andrianaki, A.M., et al., Iron restriction inside macrophages regulates pulmonary host defense against Rhizopus species. Nat Commun, 2018. 9(1): p. 3333.

43. Cen, H., et al., Association of IFIH1 rs1990760 polymorphism with susceptibility to autoimmune diseases: a meta-analysis. Autoimmunity, 2013. 46(7): p. 455-62.

44. Kato, H., et al., Differential roles of MDA5 and RIG-I helicases in the recognition of RNA viruses. Nature, 2006. 441(7089): p. 101-5.

45. Domsgen, E., et al., An IFIH1 gene polymorphism associated with risk for autoimmunity regulates canonical antiviral defence pathways in Coxsackievirus infected human pancreatic islets. Sci Rep, 2016. 6: p. 39378.

46. Odendall, C., et al., Diverse intracellular pathogens activate type III interferon expression from peroxisomes. Nat Immunol, 2014. 15(8): p. 717-26.

47. Dixit, E., et al., Peroxisomes are signaling platforms for antiviral innate immunity. Cell, 2010. 141(4): p. 668-81.

48. Jaeger, M., et al., The RIG-I-like helicase receptor MDA5 (IFIH1) is involved in the host defense against Candida infections. Eur J Clin Microbiol Infect Dis, 2015. 34(5): p. 96374.

49. Pappas, P.G., et al., Invasive candidiasis. Nat Rev Dis Primers, 2018. 4: p. 18026.

50. De Pauw, B., et al., Revised definitions of invasive fungal disease from the European Organization for Research and Treatment of Cancer/Invasive Fungal Infections Cooperative Group and the National Institute of Allergy and Infectious Diseases Mycoses Study Group (EORTC/MSG) Consensus Group. Clin Infect Dis, 2008. 46(12): p. 1813-21.

51. Goncalves, S.M., et al., Evaluation of Bronchoalveolar Lavage Fluid Cytokines as Biomarkers for Invasive Pulmonary Aspergillosis in At-Risk Patients. Front Microbiol, 2017. 8: p. 2362.

52. Gray, R.J., A Class of K-Sample Tests for Comparing the Cumulative Incidence of a Competing Risk. The Annals of Statistics, 1988. 16(3): p. 1141-1154.

53. Scrucca, L., A. Santucci, and F. Aversa, Competing risk analysis using R: an easy guide for clinicians. Bone Marrow Transplant, 2007. 40(4): p. 381-7. 
medRxiv preprint doi: https://doi.org/10.1101/2021.08.07.21261611; this version posted August 8, 2021. The copyright holder for this preprint (which was not certified by peer review) is the author/funder, who has granted medRxiv a license to display the preprint in perpetuity.

It is made available under a CC-BY-NC-ND 4.0 International license.

494 Table 1. Multivariate analysis of the association of IFIH1 and MAVS SNPs with the risk of

495 invasive pulmonary aspergillosis among transplant recipients.

\section{Genetic/clinical variables}

\section{Adjusted HR $\uparrow$ \\ $(95 \% \mathrm{CI})$ \\ P value}

497

\begin{tabular}{lll}
\hline Donor rs17857295 in $M A V S$ & $2.39(1.07-5.32)$ & 0.033
\end{tabular}

498

$$
\text { Recipient rs1990760 in IFIH1 } \quad 1.46(0.89-2.40) \quad 0.121
$$

499
Acute GVHD grades III-IV
$1.73(0.94-3.19)$
0.047

500

501 HR, hazard ratio; CI, confidence interval. Multivariate analyses were based on the

502 subdistribution regression model of Fine and Gray. $\uparrow$ Hazard ratios were adjusted for patient age

503 and gender, and clinical variables with a $\mathrm{P}<0.15$ in the univariate analyses. Only the variables

504 remaining significant after adjustment are shown. 
medRxiv preprint doi: https://doi.org/10.1101/2021.08.07.21261611; this version posted August 8, 2021. The copyright holder for this preprint (which was not certified by peer review) is the author/funder, who has granted medRxiv a license to display the preprint in perpetuity.

It is made available under a CC-BY-NC-ND 4.0 International license .
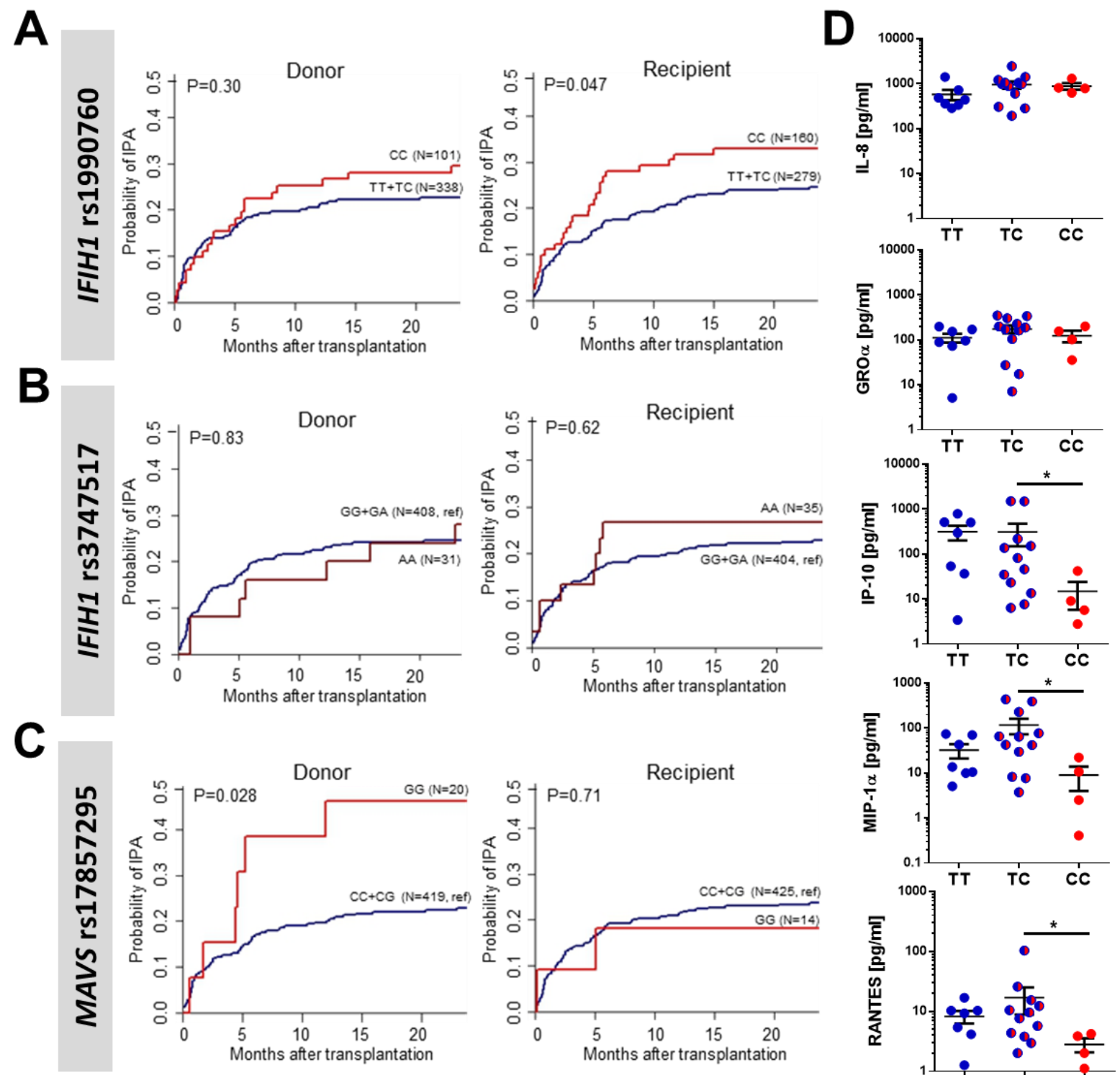

Figure 1. IFIH1 and MAVS polymorphisms are associated with invasive pulmonary aspergillosis in human transplant patients using a recessive allele model. Cumulative incidence analysis of invasive aspergillosis after transplantation according to donor or recipient genotypes at rs1990760 in IFIH1 (A), rs3747517 in IFIH1 (B), or rs17857295 in MAVS (C) over 24 months after HSCT. Data were analyzed by two-sided Gray's test. (D) Inflammatory cytokine levels in the bronchoalveolar lavage fluid from 23 patient with invasive pulmonary aspergillosis were measured using a 32-plex ProCarta Luminex assay and plotted based on their IFIH1 rs 1990760 genotype. Data were analyzed using a Mann-Whitney U-test $(* \mathrm{p}<0.05)$. 

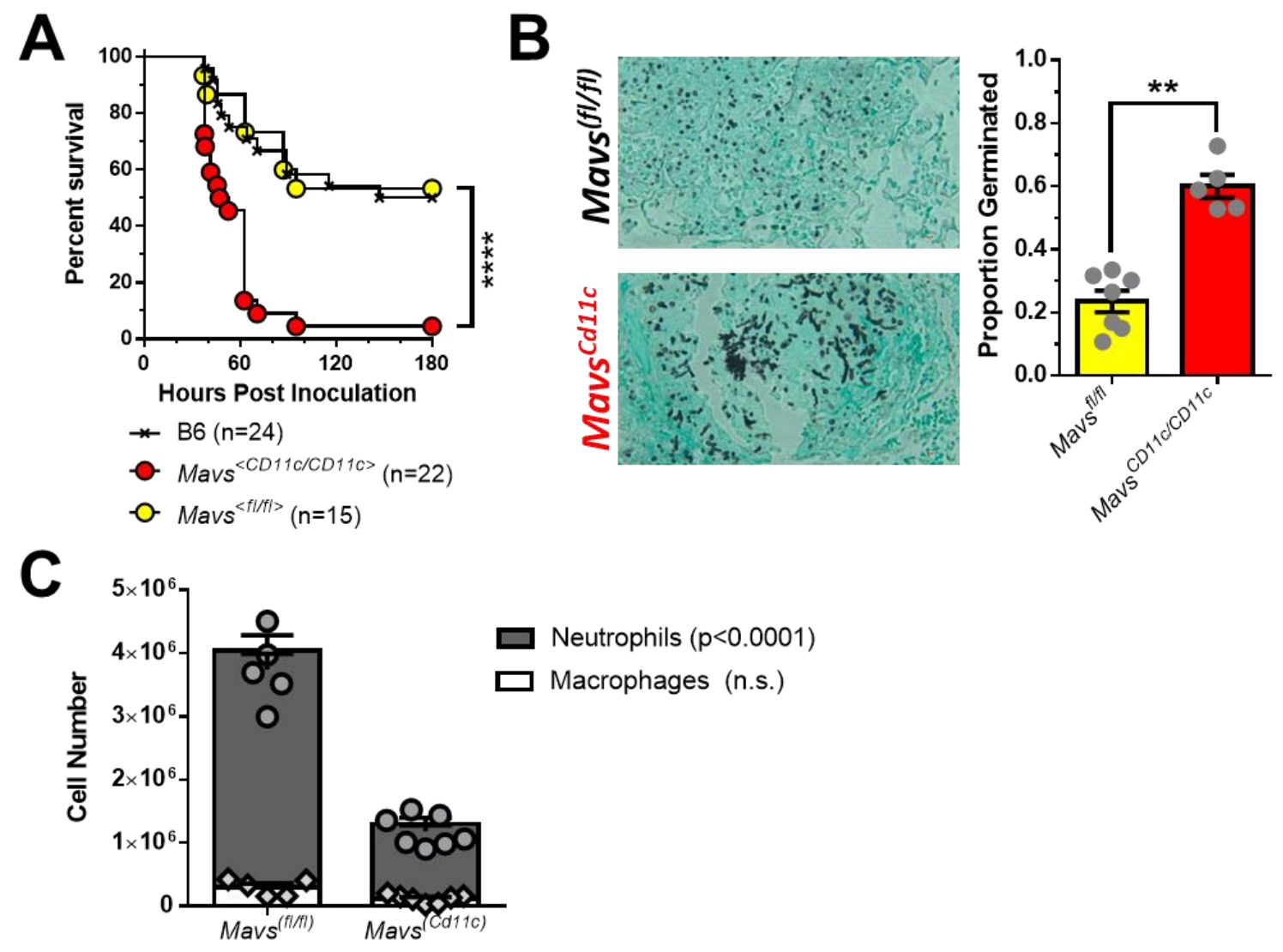

Neutrophils $(p<0.0001)$

Macrophages (n.s.)

Figure 2. Mavs-dependent responses are essential in $\mathrm{CD}_{11}{ }^{+}$cells for host resistance against Aspergillus fumigatus. Mavs ${ }^{<C d 11 c / C d 11 c>}$, Mavs $^{<f l f l>}$ and C57BL/6J mice were challenged i.t. with $4 \times 10^{7}$ resting conidia of the CEA10 isolate of Aspergillus fumigatus. (A) Survival analysis in immune-competent wild-type and knock-out mice were tracked over the first 9 days. ****, $\mathrm{P}<$ 0.0001 by Mantel-Cox log rank test. (B) Forty hours after A. fumigatus challenge mice were euthanized and fungal germination was assessed in the lungs by GMS staining. **, $\mathrm{P}<0.01$ by Mann-Whitney U-test. (C) At the same time point, cell differentials in the lung airways was determined by differential staining of BALF cytospins. Statistical significance was determined using a two-way ANOVA with a Sidak's post-test. 
medRxiv preprint doi: https://doi.org/10.1101/2021.08.07.21261611; this version posted August 8, 2021. The copyright holder for this preprint (which was not certified by peer review) is the author/funder, who has granted medRxiv a license to display the preprint in perpetuity.

It is made available under a CC-BY-NC-ND 4.0 International license .
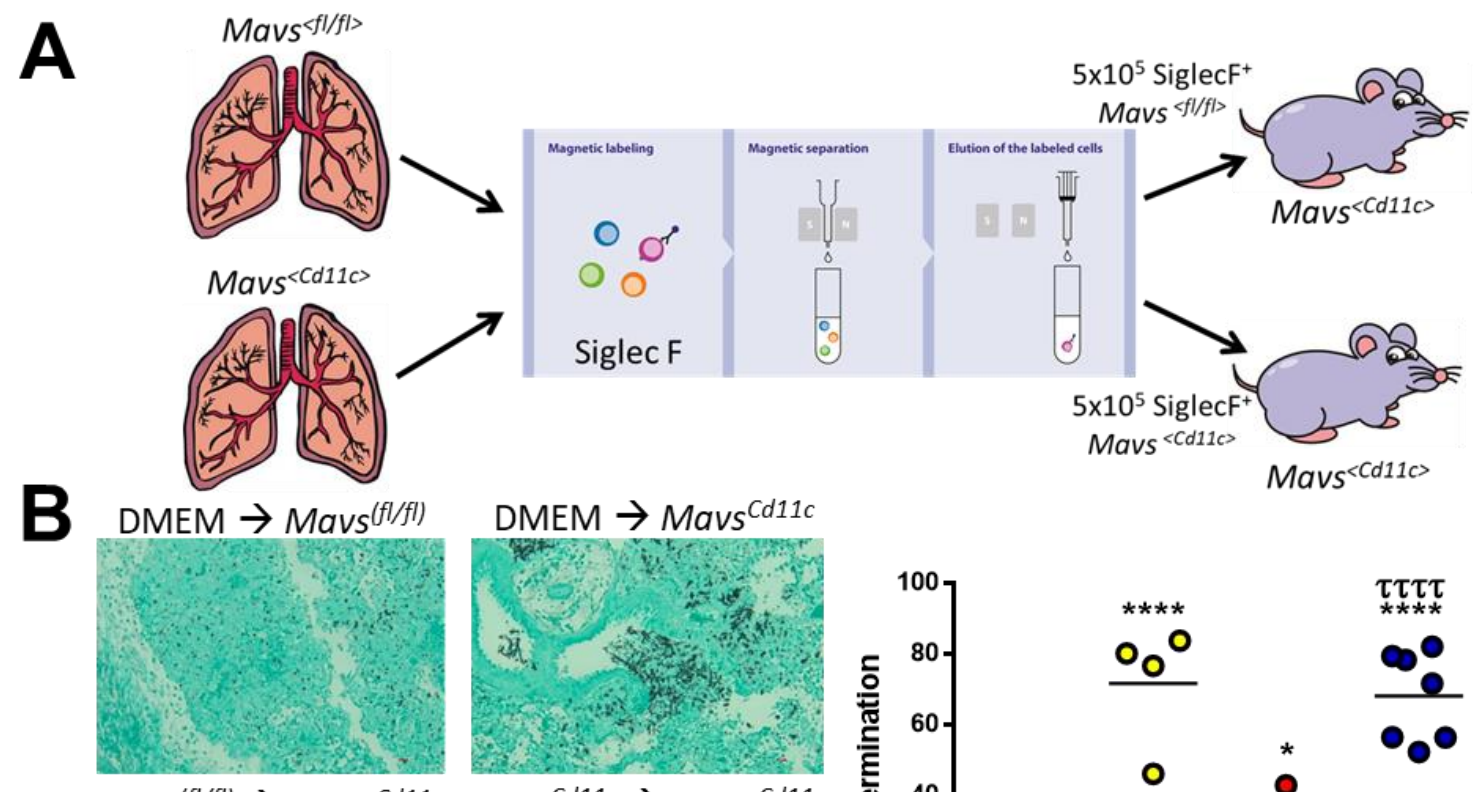

DMEM $\rightarrow$ Mavs $^{C d 11 c}$
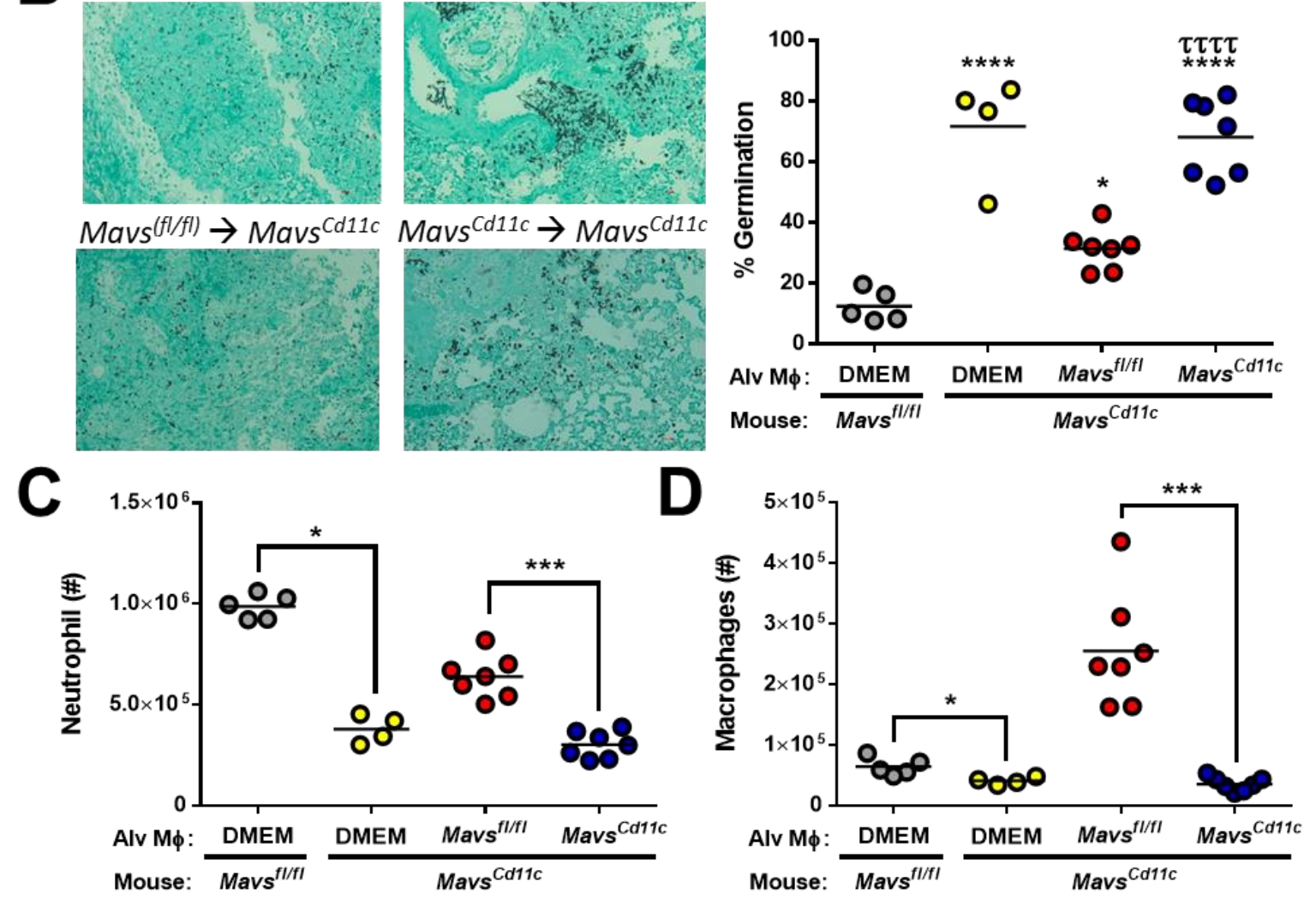

Figure 3. Alveolar macrophages require a Mavs-dependent response to maintain host resistance

(Siglec $\mathrm{F}^{+}$) given intranasally. One day later mice were challenged i.t. with $4 \times 10^{7}$ resting conidia of the CEA10 isolate of Aspergillus fumigatus. Forty hours after A. fumigatus challenge mice were euthanized. (B Fungal germination was assessed in the lungs by GMS staining. Representative 20x GMS images are shown. Statistically significant different were determined using a one-way ANOVA with a Tukey's post-test: *p<0.05 (vs. DMEM $\rightarrow \operatorname{Mavs}^{(f l / f l)}$ ), $* * * * \mathrm{p}<0.0001$ (vs. DMEM $\rightarrow \operatorname{Mavs}^{(f l / f l)}$ ), and $\tau \tau \tau \tau \mathrm{p}<0.0005$ (vs. Mavs $^{(f l / f l)} \rightarrow$ Mavs $^{(C d l l c)}$ ). Neutrophils (C) and macrophages (D) in the lung airways was determined by differential staining of BALF cytospins. 
medRxiv preprint doi: https://doi.org/10.1101/2021.08.07.21261611; this version posted August 8, 2021. The copyright holder for this preprint (which was not certified by peer review) is the author/funder, who has granted medRxiv a license to display the preprint in perpetuity.

It is made available under a CC-BY-NC-ND 4.0 International license .

540 Supplemental Table 1. Baseline characteristics of transplant recipients enrolled in the study.

\begin{tabular}{lccc}
\hline Variables & $\begin{array}{c}\text { IPA } \\
(n=91)\end{array}$ & $\begin{array}{c}\text { No IPA } \\
(n=348)\end{array}$ & P value
\end{tabular}

Age at transplantation, no (\%)

$\begin{array}{lcc}\leq 20 \text { years } & 13(14.3) & 69(19.8) \\ 21-40 \text { years } & 23(25.3) & 101(29.0) \\ >40 \text { years } & 55(60.4) & 178(51.2)\end{array}$

Gender, no (\%)

Female

$38(41.8) \quad 150(43.1) \quad 0.859$

Male

$53(58.2) \quad 198(56.9)$

Underlying disease, no. (\%)

Acute leukemia

$49(53.8) \quad 179(51.5)$

0.115

Chronic lymphoproliferative diseases

14 (15.4)

69 (19.8)

Myelodysplastic/myeloproliferative

$13(14.3) \quad 30(8.6)$

diseases

Chronic myeloproliferative diseases

$7(7.7)$

$20(5.7)$

Aplastic anemia

6 (6.6)

17 (4.9)

Other

2 (2.2)

$33(9.5)$

Transplantation type, no. (\%)

Matched, related

34 (37.4)

169 (48.6)

0.037

Matched, unrelated

$33(36.3) \quad 81(23.3)$

Mismatched, related

$0(0.0)$

7 (2.0)

Mismatched, unrelated

$24(26.4) \quad 91(26.2)$

Graft source, no. (\%)

Peripheral blood

$80(87.9) \quad 287(82.5) \quad 0.506$

Bone-marrow

10 (11.0)

$53(15.2)$

Cord blood

$1(1.1) \quad 8(2.3)$

Disease stage, no. (\%)

First complete remission

$49(53.8) \quad 188(54.0)$

0.800 
medRxiv preprint doi: https://doi.org/10.1101/2021.08.07.21261611; this version posted August 8, 2021. The copyright holder for this preprint (which was not certified by peer review) is the author/funder, who has granted medRxiv a license to display the preprint in perpetuity.

It is made available under a CC-BY-NC-ND 4.0 International license .

Second or subsequent remission, or relapse

Active disease

Conditioning regimen, no $(\%)$

RIC

Myeloablative

CMV serostatus of donor and recipient, no. (\%)

$\mathrm{D}-/ \mathrm{R}+$ or $\mathrm{D}+/ \mathrm{R}+$

D-/R- or D+/R-

Duration of neutropenia, mean days (range) $\dagger$

Acute GVHD, no. (\%)

No GVHD or grades I - II

Grades III - IV

Antifungal prophylaxis, no. (\%)\$

Fluconazole

Posaconazole

Other

None or unknown
$13(14.3)$

$59(17.0)$

$29(31.9) \quad 101(29.0)$

$68(74.7) \quad 228(65.5)$

0.091

$23(25.3) \quad 120(34.5)$

$\begin{array}{lll}80(87.9) & 313(89.9) & 0.504 \\ 11(12.1) & 35(10.1) & \end{array}$

$13.1(8-\quad 13.5(5-35) \quad 0.460$ 39)

$63(69.2) \quad 302(86.8)$

0.0002

$28(30.8) \quad 46(13.2)$

42 (46.2)

$117(33.6)$

0.002

$26(28.6) \quad 107(30.8)$

9 (9.9)

$14(4.0)$

$14(15.4) \quad 110(31.6)$

542 Twenty-one patients with "possible" IPA were excluded. Chronic lymphoproliferative diseases 543 included cases of chronic lymphocytic leukemia, multiple myeloma, and B- and T-cell 544 lymphomas. Chronic myeloproliferative diseases included cases of chronic myelogenous leukemia 545 and primary myelofibrosis. Other diseases included cases of idiopathic medullar aplasia, 546 lymphohistiocytosis, hemoglobinopathies and paroxysmal nocturnal hemoglobinuria. RIC, 547 reduced intensity conditioning; CMV, cytomegalovirus; D, donor; R, recipient; GVHD, graft548 versus-host-disease. $†$ Neutropenia was defined as $\leq 0.5 \times 10^{9}$ cells $/ \mathrm{L}$. $†$ Other antifungals used in 549 prophylaxis included voriconazole, liposomal amphotericin B, itraconazole and caspofungin. $\mathrm{P}$ 550 values were calculated by Fisher's exact probability t-test or Student's t-test for continuous 551 variables. 
medRxiv preprint doi: https://doi.org/10.1101/2021.08.07.21261611; this version posted August 8, 2021. The copyright holder for this preprint (which was not certified by peer review) is the author/funder, who has granted medRxiv a license to display the preprint in perpetuity.

It is made available under a CC-BY-NC-ND 4.0 International license .
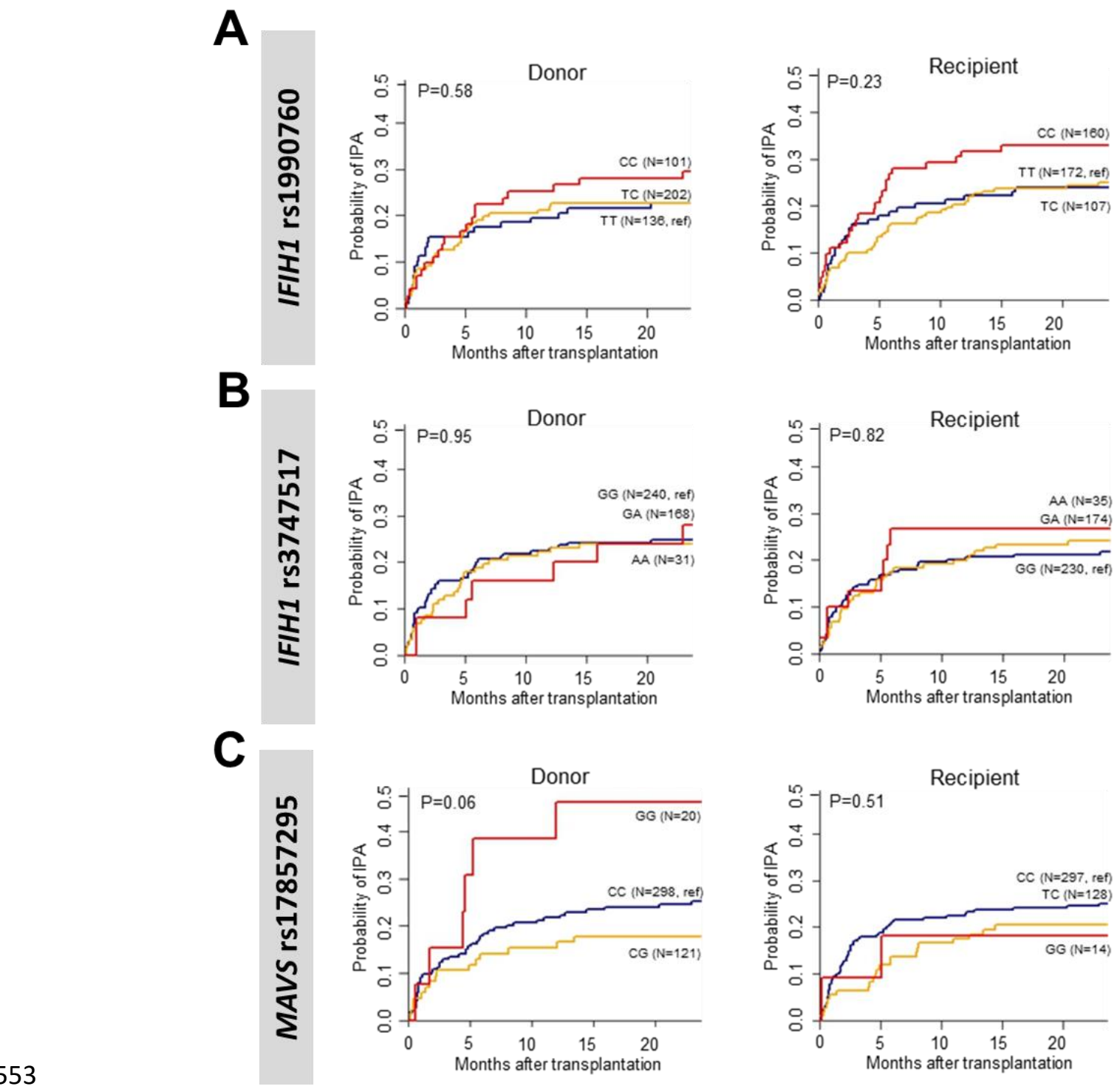

Supplemental Figure 1. Individual genotype of IFIH1 and MAVS polymorphisms in human transplant patients. Cumulative incidence analysis of invasive aspergillosis after transplantation according to donor or recipient genotypes at rs1990760 in IFIHI (A), rs3747517 in IFIHI (B), or rs 17857295 in MAVS (C) over 24 months after HSCT. Data were analyzed by two-sided Gray's 558 test. 
A

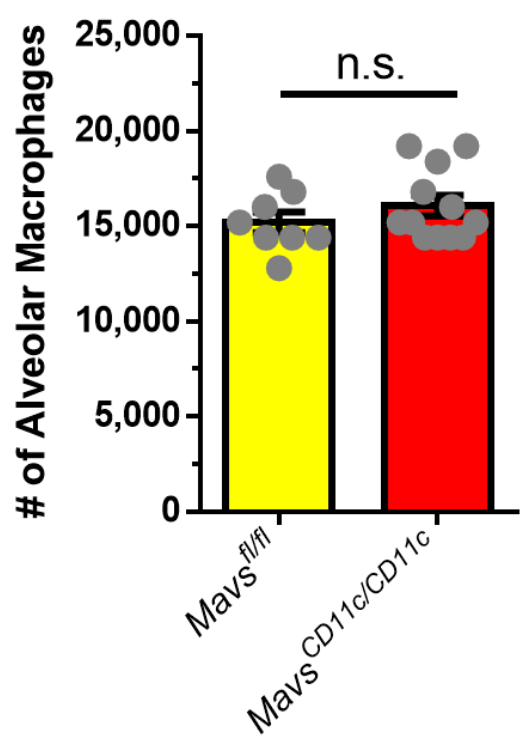

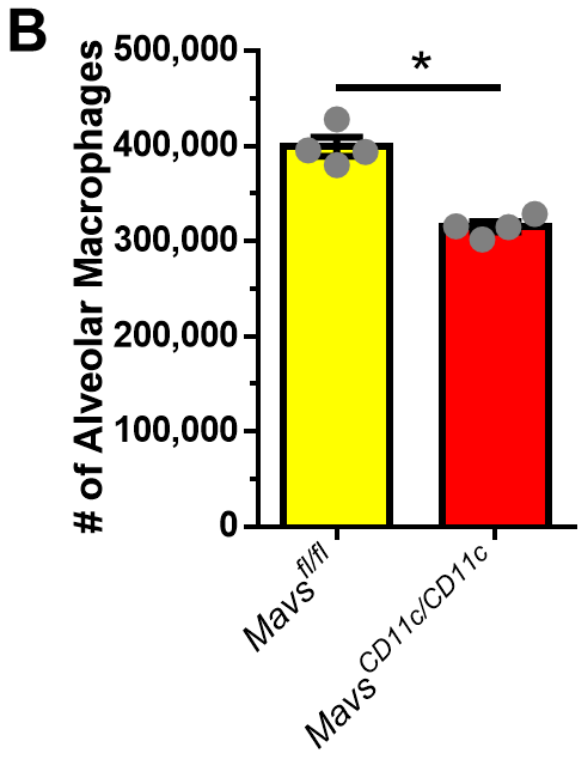

Supplemental Figure 2. Alveolar macrophage numbers are normal in naïve mice. BAL cells from naïve $M a v s^{\langle C d 11 c / C d 11 c\rangle}$ and $M a v s^{\langle f l f l\rangle}$ mice (A) or naïve $M a v s^{\langle C d 11 c / C d 11 c\rangle}$ mice given $5 \times 10^{5}$ SiglecF $^{+}$lung cells from naïve $\mathrm{Mavs}^{\langle C d 11 c / C d 11 c\rangle}$ and $\mathrm{Mavs}^{\langle\mathrm{flfl}\rangle}$ mice $24 \mathrm{~h}$ prior (B) were collected in PBS/EDTA. Alveolar macrophage numbers were quantified by Cytospin analysis and differential staining. n.s. = not significant; * $\mathrm{P}<0.01$; by Mann-Whitney U-test. 